Отримано: 12 листопада 2021 p.

Прорецензовано: 2 грудня 2021 р.

Прийнято до друку: 3 грудня 2021 р.

e-mail: natalylutsk@gmail.com

tatianakiev99@gmail.com

DOI: $10.25264 / 2519-2558-2021-12(80)-34-38$
Одарчук Н. А., Мірончук Т. А. Невербальна комунікація у православній церкві в нових реаліях. Наукові записки Начіонального університету "Острозька академія»: серія «Філологія». Острог : Вид-во НаУОА, 2021. Вип. 12(80). С. 34-38.

\author{
Одарчук Наталія Андріївна, \\ кандидат філологічних наук, дочент, \\ Волинський національний університет імені Лесі Украйнки \\ Мірончук Тетяна Андріївна, \\ кандидат філологічних наук, дочент, \\ Київський начіональний університет імені Тараса Шевченка
}

УДК: 81 ’22 : 271.22(477)

НЕВЕРБАЛЬНА КОМУНІКАЦІЯ У ПРАВОСЛАВНІЙ ЦЕРКВІ В НОВИХ РЕАЛІЯХ

Стаття присвячена змінам, які відбулися у сфері невербальної комунікації у православній церкві із настанням пандемії коронавірусної хвороби Covid-19. Піддаються аналізу такі канали невербальної передачі інформаиї, як кінесика, гаптика, проксеміка, паравербаліка, такесика, гастика. 3'ясовано, щуо найсуттєвіших змін зазнала проксеміка - використання простору, ияо відобразилося на значному скороченні дозволеної для перебування на богослужінні кількості парафіян до 10-15 і встановлення між ними сочіальної дистаниї не менше 1,5-2 метри. Одяг, який є візуальним знаком, доповнився обов'язковою для прихожан і священників маскою на обличчі. Почілунок, як елемент гаптики, заборонений із початку карантинних обмежень, натомість він замінений на кінесичний невербальний знак поклону перед іконами, хрестом, чашею чи священником в знак пошани і благоговіння. Невербальний канал гастика доповнився такесичним - використання долонь при прийнятті Святих Дарів. Зміни у хронеміиі відображаються у затягуванні в часі богослужінь, зокрема Літургї, у святкові дні через заборону загальної сповіді. Паравербальний канал зазнав змін через кількісне скорочення більшості иерковних хорів до кількох співців, цио відобразилося на якості звучання піснеспівів, як результат - багатоголосний партесний спів замінений на одно- чи двоголосний.

Ключові слова: невербальна комунікація, православна ичерква, кінесика, гаптика, проксеміка, паравербальна комунікація, ольфакторний знак, такесика.

Nataliia Odarchuk,

PhD in Philology, Associate Professor,

Lesya Ukrainka Volyn National University

Tetiana Mironchuk,

PhD in Philology, Associate Professor,

Taras Shevchenko National University, Kyiv

\title{
NON-VERBAL COMMUNICATION IN THE ORTHODOX CHURCH IN NEW REALITIES
}

The article focuses on the changes that have taken place in the sphere of non-verbal communication in the Orthodox Church with the onset of the Covid-19 coronavirus pandemic. Such channels of nonverbal information transmission as kinesics, haptics, proxemics, paraverbals, tacesics, gastics have been analyzed. The conducted research reveals proxemics - the use of space as the most significant change, which was reflected in a significant reduction in the number of parishioners allowed to attend church services to 10-15 and the establishment of a social distance between them of at least 1,5-2 metres. The clothing, a visual sign, was complemented by a mandatory face mask for parishioners and priests. A kiss, as an element of haptics, has been forbidden since the beginning of quarantine restrictions, it is replaced by a kinesic nonverbal sign of a bow in front of icons, a cross, a chalice, or a priest as a symbol of reverence and awe. Gastic nonverbal channel is supplemented with a tacesic one - the use of palms when communing. Changes in chronemics are represented by delays in Liturgy on holidays. Paraverbal channel has undergone changes due to the quantitative reduction of most church choirs to a few singers, which has affected the sound quality of the hymns, as a result polyphonic party singing has been replaced by one- or two-part.

Key words: non-verbal communication, Orthodox Church, kinesics, haptics, proxemics, paraverbal communication, olfactory sign, tacesics.

Постановка проблеми. Невербальна комунікація - досить потужний вид спілкування, для якого характерне використання безсловесної поведінки, а саме: жестів, міміки, постави, погляду, мовчання, використання запахів, простору тощо. Вона неодноразово ставала об'єктом, предметом, матеріалом дослідження вітчизняних і зарубіжних лінгвістів, соціологів, психологів. Визначні праці таких науковців, як А. Піз, І. Н. Горєлов, Г. Є. Крейдлін $[5 ; 7 ; 8]$ та інших стали енциклопедичними для застосування не лише у лінгвістичній науці, але й в психології стосунків, гендерних студіях, міжкультурній взаємодії, менеджменті підприємницької діяльності тощо. Дослідження невербальних каналів у релігійному дискурсі не частотні, радше фрагментарні: М. Петрушкевич описує невербальну комунікативну систему з філософсько-культурологічної точки зору [9], елементи аналізу цієї форми комунікації знаходимо у монографії О. Бобирєвої [3], паравербаліці значна роль відведена в дисертації М. Антоненко [1].

Проте недослідженими дотепер залишаються зміни у вираженні невербальної знаковості в православній церкві, які сталися із розповсюдженням пандемії коронавірусної хвороби Covid-19 та запровадженням карантинних обмежень. Саме в проведенні аналізу цих змін полягає мета нашої розвідки.

Виклад основного матеріалу. Передача інформації, організація інтеракції, здійснення впливу на слухача, формування власного іміджу чи думки про співрозмовника тощо може відбуватися за допомогою як словесної комунікації, так і невербальних знаків. За підрахунками дослідників 69\% інформації в різних сферах суспільного життя припадає на невербальну комунікацію [10, с. 302]. Американський дослідник Альберт Мехрабіен довів, що взаємодія між людьми на $93 \% \in$ невер- 
бальною, у його відомій формулі 7-38-55 лише 7\% переданої інформації є словесною, 38\% припадає на голосові модуляції (висота, тембр, інтонація) і 55\% - на мову тіла людини [14]. Не в кожному виді спілкування, звісно, ця формула застосовується, під час лекції професора перед студентами чи у проповіді священника перед парафіянами, наприклад, основний “тягар” покладено на словесну складову.

Невербальна комунікація охоплює широкий спектр сигналів поведінки людини і включає такі підвиди: паралінгвістика - використання голосу, а саме гучність, темп мовлення, інтонація, тембр, крім того, паралінгвістика вивчає покашлювання, заїкання, плач, індивідуальні голосові модуляції; проксеміка - використання простору, як індивідуальної, так і соціальної дистанції і їхнього впливу на взаємодію. Кінесика, як розділ невербалістики, ставить за мету довести роль виразу обличчя, усмішки, жестів, рухів тіла, постави у процесі людської інтеракції, а ії підвид - окулесика - займається вивченням кінем очей, погляду. Гаптика вивчає доторки, зокрема поцілунки, їхню символіку; підвидом гаптики $є$ такесика, об'єктом дослідження якої є рукостискання, поплескування, обійми, зокрема при привітанні і прощанні. Окремим видом невербальної комунікації є хронеміка - використання часу в інтеракції між людьми, а ольфакція займається вивченням запахів і використання їх у соціальній взаємодії. Гастика - наука про приготування й споживання їжі, поведінку за столом та харчову символіку. Одяг людини також набуває лінгвістичної інтерпретації як важливий візуальний знак невербальної інтеракції [12].

У православній церкві невербальна комунікація займає вагоме місце в священнодійствах: під час Літургії, молебнів, акафістів, вечірніх і всенічних служб, під час таїнств невербальні знаки несуть глибокі символічні смисли. Символ наділений вищим статусом ніж слово, оскільки символ колективний, а слово одночасно і колективне, й індивідуальне [10, с. 14]. У православній церкві використовуються такі семіотично значимі рухи, пози і жести, як поясні та земні поклони (кінесика), хресне знамення (такесика), клякання (кінесика) - як вияв пошани і благоговіння, підняті до неба очі (окулесика) і руки (такесика), особливі жести благословення священника (такесика), ритуальне цілування руки священника (гаптика), омовіння рук священником (такесика) та інші. У православ'ї виникає феномен наслідування, коли віруючі повторюють рухи священнослужителя. Більшість жестів та поз під час богослужіння, зокрема літургійного дійства (підняття рук, поклони, опускання голови, ставання на коліна), є типовими, які прийшли з давніх часів, інколи навіть язичницьких, а тому сприймаються як певний обов'язковий тип поведінки під час сакрального дійства [9, с. 48]. У процесі храмового дійства група осіб - від священнослужителів до кліриків, півчих і читців - на основі різновидів культового мистецтва: речитативів, музики, живопису, архітектури - втілюють величну культову дію. Храмова комунікація у більшості випадків вимагає обізнаності із символікою, позаяк незнання символічного ряду закриває можливість передачі інформації [9, с. 50].

Одним із церковних символів є кадило. Відповідно до класифікації невербальних знаків кадило - ольфакторний знак, так як ладан, що використовується у ньому, діє на нюхові рецептори, від яких нервові імпульси передаються у проміжний мозок, потім у лобову частину кори, де проходить аналіз речовин, що вдихаються. Кадило - це символ молитви, оскільки, “як дим ладану піднімається вгору, так і молитва сходить до Бога” [Одкр. 8:4 і Пс. 141:2]. Подібну функцію виконують свічки, вони використовуються як символи Господа нашого Ісуса Христа, “Який є Світлом Світу” [Івана 8:12; 9:5]. Переважно свічки, які використовуються у православній церкві - воскові, тому при згоранні виділяється приємний аромат, так само як і при обкаджуванні церкви ладаном, а це відволікає вірян від усього мирського, земного і налаштовує на молитву, священнодійство. Крім того, використання свічок психологічно стимулює людину говорити тихіше, висловлювати інтимні думки та почуття [9, с. 54].

Сьогоднішня ситуація із пандемією Covid 19 не могла не відобразитися як на церковній складовій життя вірних, так i на самій церкві. Із початку 2020 року весь світ живе у новій реальності. Швидке поширення коронавірусної інфекції змусило медиків, і не лише їх, до швидкого реагування, адже в скорому часі пандемія Covid 19 перестала бути лише медичною проблемою. Через високий рівень ії контагіозності увесь світ максимально перейшов на роботу і навчання он-лайн, скасувалися всі масові заходи, що передбачали велике зібрання людей, а на територіях високої епідемічної небезпеки був запроваджений повний локдаун. Світ поступово навчився жити по-новому.

Впродовж всього свого існування церква залишається дещо консервативною інституцією, вірною усталеним тисячолітньою історією традиціям, з іншого боку, вона є гнучкою системою, яка реагує на виклики часу. Церква об'єднує вірних, які в свою чергу є громадянами суспільства, в якому живуть, тому їхні проблеми автоматично стають проблемами церкви. Із початком пандемії Covid-19 в православній церкві відбулися чималі зміни. В часи війн, лихоліть, особистих переживань чи сімейних негараздів українцям, як досить релігійній нації, властиво звертатися до Бога, до церкви, де людина завжди віднаходила втіху, душевний спокій, емоційну й духовну підтримку.

Однак в нових реаліях стосовно релігійного аспекту життя на парафіян наклалися певні обмеження. Церква не змінила своїх канонів, тим більше догматів, главою її так само залишається Ісус Христос, вона не перестала бути інституцією, що об’єднує вірних. Проте поширення пандемії призвело до певних змін, в тому числі змін у невербальній комунікативній поведінці у храмі. Насамперед, це відобразилося на проксеміці. Із початку введення карантину в країні дозволялося перебування в церкві не більше 10-15 людей: "Під час богослужінь у храмі мають бути присутні священнослужителі та церковнослужителі, чтеці та співиі, інші особи, які беруть участь у звершенні богослужінь та забезпеченні трансляцї (у разі ї̈̈ здійснення) - спільною загальною кількістю не більше 10 осіб” [11]. Решті прихожан дозволялося знаходитися на церковному подвір'ї за умови дотримання соціальної дистанції не менше 1,5-2 метри між вірянами, для цього введена спеціальна розмітка (візуальний невербальний знак). В Україні Пасхальна служба 2020 року не була заборонена, але проводилася із зазначеними обмеженнями, натомість в українських православних церквах за кордоном служби в період жорстких локдаунів, велися виключно одним священником у храмі, якому співслужив чтець, він поєднував функції хору, і транслювалися служби онлайн через різні канали.

Найефективнішим місцем для реалізації символів $\epsilon$ візуальне середовище, адже, повертаючись до формули А. Мехрабіена, більше 50\% всієї інформації людина сприймає через зір. Візуальна символіка виступає в ролі об'єднувача, несе функцію інтенсифікації, тобто підсилює текстове повідомлення - молитву, спів, проповідь. Цим вона забезпечує багатоканальність впливу, до якого і прагне священик. Орієнтація у просторі християнського храму можлива при наявності 
у віруючого досвіду декодування. Таким чином, релігійний простір сприймається у процесі безпосередньої взаємодії, спостереження, під час якого він прочитується через елементи, що його заповнюють [4, с. 199]. Повідомлення, які передаються декількома каналами, мають корегуватися між собою, тобто релігійна служба має співпадати з урочистістю інтер'єру храму, а також пишністю одягу священнослужителя, кожен елемент якого має глибокий символічний зміст і несе певне смислове навантаження [9, с. 50]. Стосовно такого невербального знаку, як одяг, то він зазнав зміни лише в тому, що всі прихожани зобов'язані одягати маску на обличчя, яка закриває рот і ніс, і перебувати в ній до закінчення служби. Церковнослужителі не стали винятком, вони керуються Практичними настановами Священного Синоду ПЦУ від 24 березня 2020 року. Без маски священнику дозволяється перебувати у вівтарі, на амвоні, звідки виголошується проповідь, але під час сповіді парафіян, наприклад, або під час кадіння всієї церкви, коли священнослужитель перебуває в безпосередній близькості до вірних, він одягає маску.

Найбільші зміни відобразилися на таких каналах невербальної поведінки, як гаптика, такесика, адже пандемія повністю “заборонила" цілування ікон, хрестів, інших святинь, а також руки священника. "На час пандемії достатнім виявом шанування святинь (Хреста, ікон, святих мощей) є поклоніння/поклон перед ними, без цілування; зазначене також застосовується до особистих вітань та вияву пошани між членами Церкви, зокрема між священнослужителями і мирянами під час подання благословення. При поданні благословення Хрестом - достатньо здійснити осінення ним, без иілування" [11]. Православному християнину ікони, через які підсилюється невербальне повідомлення храму, як комунікативного транслятора, допомагають відірватися від усього земного, вони відкривають йому доступ до пізнання трансцендентного світу. При такому трактуванні ікони будь-який представлений образ намагаються дематеріалізувати, щоб придушити в ньому всі сенсуалістичні моменти, які хоч трохи протистоять вираженню глибокої одухотвореності [9, с. 53]. Отже, православний християнин через образ, зображений на іконі, бачить первообраз - Ісуса Христа, Пресвяту Богородицю, святих мучеників, праведників тощо, а тому поклоняючись і цілуючи ікону, вірні виявляють шану саме їм. А цілуючи хрест, православні “бачать” розіп'ятого Христа, який страждав, але, воскреснувши, подолав смерть, отож хрест - це знамення перемоги. Із поширенням пандемії невербальний знак поцілунку, який належить до гаптики, був замінений на поклон, який у класифікації невербальний знаків відноситься до кінесичних, зокрема постави, положення тіла.

В православній церкві поцілунку завжди відводилося особливе місце, позаяк в традиції давньохристиянської церкви він був символом любові і миру. Апостол Павло настановляв вітати один одного “цілуванням святим” [Коринф. 16:20]. Святим поцілунок вважається ще й тому, що диявол роз'єднує людей, а поцілунок здатний їх знову об'єднати [6, с. 44]. Прийняте цілування руки священника мирянином символізує не вияв поваги до священнослужителя, а вбачання у ньому самого Бога, Який благословляє Своєю десницею. До того ж, часто цілується зазвичай не зворотна частина долоні, а поручі - елемент одягу, який символізує руку самого Господа, одягнувши які і зав'язавши навколо зап'ястя, вже не людина, а сам Бог творить Своєю рукою. 3 поширенням пандемії Covid-19 поцілунок, гаптичний невербальний знак, був замінений на поєднання двох інших: кінесичний і такесичний. Такесика - підрозділ гаптики, який вивчає рух чи положення рук, рукостискання тощо. Отож замість поцілунку віряни схиляють голову перед священнослужителем (кінесика), який в знак благословення правицею осіняє вірянина хресним знаменням, покладаючи руку йому на голову (кінесичний і такесичний невербальні знаки).

Інший невербальний канал комунікації в храмі - хронеміка - вивчення ролі часу в інтеракції. Те, як людина цінує і сприймає час, відіграє значну роль в іiі процесі спілкування; сприйняття часу включає пунктуальність, взаємодію і готовність чекати. Використання часу може вплинути на спосіб життя, повсякденний уклад, швидкість мови, руху і на те, як довго люди готові слухати. В глобальному релігійному контексті хронеміка - значущий невербальний канал, який поєднує минуле, теперішнє й майбутнє людства в цілому й кожного вірянина зокрема. Через правильне трактування уривку зі Святого Письма, написаного кілька тисячоліть тому, вірні отримують дороговказ для свого теперішнього життя, а завдяки праведному сьогоденню Православна церква (і не лише вона) “обіцяє” їм благе майбутнє після відходу із земного життя.

У безпосередньо церковному контексті хронеміка включає початок і закінчення богослужінь, тривалість Літургії, Всенічної, акафістів, вранішніх і вечірніх молитовних правил, час, відведений для сповіді, хрещення, вінчання тощо. За фактором сприйняття часу православну церкву можна віднести до поліхронного середовища. На відміну від монохронної системи часу, якій характерне виконання справ одна за одною, в якій час поділяється на маленькі точні одиниці, де він планується, упорядковується та управляється, поліхронічні системи значно менше орієнтовані на точність обліку часу. Вони більше орієнтовані на збереження традицій та стосунків між їі членами, а не на завдання [13]. Як результат, поліхронічне середовище має набагато менш офіційне сприйнятя часу, ним не керують точні календарі та графіки. Все вище зазначене характеризує православну церкву, адже, хоч у ній існує розклад богослужінь, вони починаються в установлені години, проте поняття часу $є$ доволі нестабільним і може легко розширюватися, або стискатися за необхідності. Священник глибше зосереджений на виконанні своєї ролі духівника, наставника, порадника, тому може коригувати час, відведений, наприклад, для сповіді вірних, щоб приділити їм більше уваги. У зв'язку з тим, що під час пандемії на служби приходить обмежена кількість людей, в багатьох церквах було запроваджено правило, що інші парафіяни можуть прийти на сповідь і причастя в будній день, посповідатися в суботу на вечірній або в неділю перед Літургією, щоб уникнути скупчення людей, що заборонено карантинними правилами. "При здійсненні Таӥнства Сповіді, турбуючись про ближніх та щуоби не давати приводу для спокуси, максимально дотримуватися загальних правил щуодо сочіальної дистаниії та вищевикладених настанов та допускати практику загальної сповіді", - читаємо у рішеннях Священного Синоду від 24 березня 2020 року [11].

Дещо затримуються служби у часі і через спосіб подачі вірним Причастя -Тіла і Крові Христових. Щодо останнього ми зосереджуємося на ще одному каналі невербальної комунікації - гастиці - науці про знакові і комунікативні функції їжі $\mathrm{i}$ напоїв, культурні особливості трапези, ії прийняття. Із настанням карантинних обмежень жодних змін не відбулося стосовно приготування Святих Дарів, а щодо їх споживання Священний Синод Православної церкви України прийняв практичні рекомендації. "Як тимчасовий надзвичайний захід дозволясться здійснювати причастя вірних Тіла і Крові Христових у той самий спосіб, як ие здійснюється священнослужителями під час Літургії Ранішеосвячених Дарів, а саме: приготовлені часточки Тіла, на які лжицею покладено частину Крові (як че робиться при приготуванні запасних Дарів) подавати з дискоса в руки (або лжицею не торкаючись уст) причаснику. При иъому слід уважно роз'яснити обов'язок причасників 
ретельно спожити Дари. Для обтирання губ використовувати одноразові серветки, які потім спалити у чистому місці. Використовувати для запивки після прийняття Причастя одноразовий посуд або споживати лише антидор” [11]. Отже, бачимо, що із введенням карантинних обмежень змінилися невербальні канали при причасті: гастика доповнилася такесикою (використання рук). Церква незмінно зберігає особливе ставлення до Євхаристії, причастя Тіла і Крові Христових, як до таїнства, що подається “на зцілення душі і тіла", а не як до споживання їжі [1 Коринф. 11:20-30]. Використання для причастя мирян того ж способу, що і для священнослужителів, продиктоване турботою про немічних у вірі [Рим. 14:1-13] та про те, щоб таїнство і церква не піддавалися безпідставній ганьбі ззовні. Цілування підніжжя чаші після причастя (гаптичний невербальний знак), що загалом прийнято в православній церкві, наразі заборонено.

Ще одним потужним каналом передачі і сприйняття храмової інформації є паралінгвістика - звуковий, слуховий канал. Віряни йдуть до церкви не лише за візуальною, але й аудіальною складовою інформації. Остання в богослужіннях представлена речитативним промовлянням єктеній, уривків з Свангелія, Апостола, читанням молитов чи співанням акафістів тощо. Проте чи не найвагоміше місце в церковній паравербаліці по праву належить хоровому співу. Підпорядковуючись Статуту канонічного священного чину, богослужіння містить чітку послідовність дій священнослужителів, чергування співу та речитативів хору та віруючих. Причому присутність музичного елемента тут вбачається невід'ємним сполучним компонентом $[1$, с. 64$]$. Як ніяке інше церковне мистецтво, хоровий спів спроможний створити молитовну атмосферу в храмі, тому він присутній в богослужінні як необхідний елемент ритуалу. Спів створює вібрацію (а хоровий спів їі посилює), тобто виявляється у певній матеріальній формі. Вібраційна природа співу здатна гармонізувати тіло людини, є своєрідною “музичною терапією”. Церковно-хорове мистецтво завжди було сферою суворої та чіткої регламентації, його характерними рисами є багатоголосся, ансамблевість, майстерність виконання. Правильно поставлений церковний спів здійснює потужний вплив на душу людини.

Окрім хорового співу невід'ємною складовою церковного мистецтва є дзвони. Музика дзвонів, як іконопис і співи, міцно закріпилася в богослужбовому вжитку. Будучи єдиним музичним інструментом у православній культурі, який дозволений церковними канонами, дзвін довершує аудіальний образ церкви. Передусім церковний дзвін призначений для того, щоб скликати віруючих до богослужіння, підносити урочистість церкви, сповіщати неприсутнім в храмі про час особливо важливих частин богослужінь. Звуки дзвонів естетично збагачують церковне богослужіння і своїм унікальним тембром привносять до обряду світло, радість, благодать [1, с.112].

Із настанням пандемії Covid-19 і накладанням карантинних обмежень церковна паравербаліка теж зазнала певних змін. Незмінними залишилися усі основні жанри православної гімнографії: псалми, тропарі, кондаки, гімни, молитви, причетні вірші, які входять у музичний цикл літургії. Організовані в традиційно сформовану систему, жанри пісень органічно вбудовані в процес богослужіння, кожен з них пов'язаний певною послідовністю, конкретними смисловими категоріями, має емоційний і поетично-музичний задум. Незмінним компонентом річного кола богослужінь залишився закон восьмиголосся. Будучи мелодичним фундаментом церковних піснеспівів, гласова система не втратила свого значення в сучасній співочій практиці і є основою виконання численних богослужбових текстів, таких як тропар, кондак, стихира, прокимен, ірмос, канон, світилен $[1,66]$. Однак через кількісне обмеження учасників богослужінь більшість церковних хорів скоротилося до кількох співців, інколи навіть одного, що відобразилося на якості звучання піснеспівів, багатоголосний партесний спів замінений на одно- чи двоголосний.

Серед $38 \%$, які забезпечують передачу інформації реципієнту тембром, голосовими модуляціями, окрема частка припадає на відсутність голосу, звуку, тобто тишу, те, що в прагмалінгвістиці називається сайленціальним мовленнєвим актом. Тиша у храмі - символічна, вона свідчить про внутрішню молитву вірян, які в цей момент перебувають в церкві. Саме в храмі людина може полюбити хвилини тиші, бо тут ця тиша не $є$ холодною самотністю, а сповнена теплої присутності Бога, радісного очікування спільної молитви. У карантинних умовах моменти тиші в церквах значно почастішали, вони знову ж спричинені невеликою кількістю парафіян, присутніх на службах, їхньою проксемічною віддаленістю один від одного, що не створює зайвого шуму, який заважає молитовному настрою.

Висновок. Отже, підсумовуючи, зазначимо, що із початком пандемії Covid-19 сталися певні зміни у невербальній комунікації в православній церкві загалом і в Україні зокрема. Найсуттєвіші стосуються проксеміки - використання простору, що відобразилося на значному скороченні дозволеної для перебування на богослужінні кількості парафіян до 10-15 в залежності від площі території храму. Додався візуальний знак розмітки в церкві і на церковному подвір'ї. Одяг, ще один візуальний знак, доповнився обов'язковою як для парафіян, так і для священників маскою на обличчі, яка повинна закривати рот і ніс, роблячи акцент на очі (окулесика). Поцілунок, як елемент гаптики, заборонений із початку карантинних обмежень, натомість він замінений на кінесичний невербальний знак поклону перед іконами, хрестом, чашею чи священником, замість цілування його руки чи поручів. Такесичний знак рукостискання при привітанні мирян один з одним - заборонений, замінений на кінесичний знак легкого нахилу голови вниз. Невербальний канал гастика доповнився такесичним - використання долонь при прийнятті Святих Дарів. Богослужіння, зокрема Літургія, затягуються в часі у святкові дні через заборону загальної сповіді, або скорочуються в будні через незначну кількість прихожан, що ілюструє зміни у хронеміці. Відсутність розмов між парафіянами під час служби (невербальний знак голос) через їхню проксемічну віддаленість на 1,5-2 метри один від одного, тобто присутність тиші, внесла зміни до паравербального каналу. Останній зазнав змін і в заміні багатоголосся церковного хору на одно- двоголосся через скорочення кількості хористів.

Перспективним у подальшому вважаємо дослідження невербальних знаків у християнських церквах різних деномінацій у порівняльному аспекті.

\section{Література:}

1. Антоненко М. М. Православна духовна музика в системі української культури кінця XX - початку XXI століття: дис. канд. мистецтвознавства: 26.00.01. / Національна музична академія України імені П. І. Чайковського. К., 2020, 269 с.

2. Біблія : Святе письмо / пер. І. Огієнка. Випр. вид. Київ : Асоціація “Духовне відродження”/ Mission Eurasia : Дорога Правди : Книгоноша, 2015. $1226 \mathrm{c}$. 
3. Бобырева Е. В. Религиозный дискурс: ценности, жанры, языковые характеристики. Монография. Волгоград : Перемена, 2007. $385 \mathrm{c}$.

4. Борисова С.А. Пространство как текстообразующая категория. Вестник Московского университета. Лингвистика и межкультурная коммуникачия. 2004. № 1. С. 199.

5. Горелов И. Н. Невербальные компоненты коммуникации. М. : Либроком, 2009. 238 с.

6. Колобова А. И. Символическое значение поцелуя в христианстве. "Magister Dixit" Научно-педагогический журнал Восточной Сибири. 2012. № 2 (06). С. 41-50.

7. Крейдлин Г. Е. Невербальная семиотика. М.: "Новое литературное обозрение, 2002. 581 с.

8. Піз А., Піз Б. Мова рухів тіла. Розширене видання / пер. з англ. К: ТОВ “Компанія ОСМА”, 2015. 416 с.

9. Петрушкевич М. С. Невербальна комунікативна система у християнських конфесіях. Українське релігієзнавство. 2006. № 38. C. $46-60$.

10. Почепцов Г.Г. Коммуникативные технологии двадцатого века. М. : “Рефл-бук”. К. : “Ваклер”, 1999. 352 с.

11. Практичні настанови у зв'язку з пандемією коронавірусної хвороби Covid-19. URL: https://www.pomisna.info/uk/documentpost/praktychni-nastanovy-dlya-yepyskopatu-duhovenstva-i-virnyh-u-zv-yazku-z-ogoloshenoyu-pandemiyeyu-osoblyvo-nebezpechnoyikoronavirusnoyi-hvoroby-covid-19/ (дата звернення 27.09.2021).

12. Argyle, Michael Bodily Communication (2nd ed.). Madison : International Universities Press, 1988. 363 p.

13. Bluedorn Allen C., Kalliath Thomas J., Strube Michael J., Martin Gregg D. Polychronicity and the Inventory of Polychronic Values (IPV) : The development of an instrument to measure a fundamental dimension of organizational culture. Journal of Managerial Psychology. 1999. Vol. 14 No. 3/4. P. 205-231.

14. Mehrabian A. Nonverbal communication. Piscataway, NJ, Aldine Transaction, 1972. 238 p. 